\title{
Analysis of reconditioning and hardening methods applied for the working tools of tillage machines
}

\author{
Ivan Golubev \\ Russian Research Institute for Information and Technical and Economic Research on the Engineering and Technical \\ Support of the Agro-Industrial Complex, 60, Lesnaya St., Pravdinsky Moscow Region, 141260, Russian Federation
}

\begin{abstract}
It is shown that tillage machines operate under conditions of abrasive wear, and their durability is largely determined by the operational life of the working tools. The main working tools of a plow include an earth board, cultivators - blades, harrows - teeth and discs, seeders - seed shoe. The working tools of tillage machines are mainly subject to abrasive wear. The blade of the soil cutting tools during operation loses its operability due to abrasive wear and therefore it must be reconditioned. There are various methods of reconditioning and hardening of working tools that increase their wear resistance and durability. The paper analyzes the methods of reconditioning and hardening of working tools of tillage machines. The study was based on information materials from Russian scientific and educational organizations and industrial companies, test reports of tillage machines conducted by machine testing stations, factographic and documentary databases of Rosinformagrotech. The generalization and analysis of information made it possible to establish that welding a blade-patch with subsequent welding of the wear-resistant material Castolin PE1229 allows increasing the life of an earth board during operation in southern chernozem soils by 4.6-5.0 times. The application of epoxy-sand composites increases the durability of earth boards by 2.2-2.7 times. Carbo-vibro-arc hardening of duckfoot teeth allows increasing the time between failures by 2.1 times compared to the serial one. Plasma spraying of powder materials increases wear resistance of duckfoot teeth by 1.5 times, and the application of pulse electric contact heating during hardening of earth boards reduces the intensity of their wear in loamy soils by more than $17 \%$.
\end{abstract}

\section{Introduction}

The largest number of high-wear working tools is installed on tillage equipment. The main working elements of a plow include landside plates, mouldboards and earth boards. Cultivators are equipped with a set of replaceable working elements (cultivator blades). Harrow working elements include teeth and discs of different diameters. The main working tools of a seeder include a plowshare designed to form furrows in the soil into which seeds are sown. Tillage machines operate under abrasive wear conditions, and their durability is largely determined by the operational life of the working tools. At the same time, a characteristic feature of most such parts is a significant amount of their wear, which for many parts may reach $2 \ldots 3 \mathrm{~mm}$, and in some cases to shape deformation (Antonov, Golubev, 2020). There are various methods to improve their durability. Their analysis made it possible to distinguish three major areas: use of new materials for the manufacture of working tools; hardening of working tools of agricultural machines during their manufacture; higher wear resistance and durability. The paper analyzes the methods of reconditioning and hardening of working tools of tillage machines.

\section{Problem Statement}

The operational and technological indicators of tillage machines do not always meet the consumer properties declared by the manufacturer. For example, according to regulatory and technical documentation, the failure time of plows should be at least 100 hours. However, the analysis showed that the time between failures of some domestic plows tested at machine testing stations (MTS) is lower than their foreign analogues. Mean Time Between Failures (MTBF) of some plows tested at machine testing stations is given in Table 1. Changes to the Rules for granting subsidies to producers of agricultural machinery will contribute to improving the reliability of tillage equipment. They also concern the quality of machines produced and must meet the criteria of the List of Criteria for Determining Functional Characteristics (Consumer Properties) and the Efficiency of Agricultural Machinery and Equipment. Data obtained from the results of tests of agricultural machinery and equipment carried out by machine testing stations under the jurisdiction of the

\footnotetext{
* Corresponding author: i.g.golubev@ mail.ru
} 
Ministry of Agriculture of the Russian Federation and data specified by the manufacturer of agricultural machinery (equipment) in technical and operational documentation are used to determine them.

Table 1. MTBF of plows tested at machine testing stations

\begin{tabular}{|c|l|c|l|}
\hline n/n & \multicolumn{1}{|c|}{ Plow mark } & MTBF, h & \multicolumn{1}{|c|}{ Machine testing station } \\
\hline 1 & PON-4/5-35 & 157 & Altaiskaya MTS \\
\hline 2 & PPO-5/6-35 & 151 & Altaiskaya MTS \\
\hline 3 & PPO-5/7-35 & 153 & Altaiskaya MTS \\
\hline 4 & PPO-6+3 & 92.5 & Altaiskaya MTS \\
\hline 5 & Agritex PNO-4 & 100 & Vladimirskaya MTS \\
\hline 6 & PPO-4+1-40K & 127 & Vladimirskaya MTS \\
\hline 7 & Euro Diamant 10 Lemken & 308 & Severo-Zapadnaya MTS, Kavkazskaya MTS \\
\hline 8 & Kverneland RN-100-8 & 153 & Vladimirskaya MTS \\
\hline
\end{tabular}

To determine the functional characteristics (consumer properties) and efficiency of agricultural machinery, the names of control parameters are determined. For example, for general purpose plows, such indicators as the depth of processing, soil pulverization, completeness of plant and crop residues embedding, depth of plant and crop residues embedding, ridgeness of the soil surface, and time between failures of a single product are monitored. MTBF of plows and harrows specified in the List of criteria for functional characteristics (consumer properties) and efficiency of agricultural machinery and equipment is given in Table 2 .

Table 2. MTBF of plows and harrows

\begin{tabular}{|c|l|c|}
\hline $\mathrm{n} / \mathrm{n}$ & \multicolumn{1}{|c|}{ Tillage machinery } & $\begin{array}{c}\text { MTBF of a } \\
\text { single tool, } \\
\text { hours, at least }\end{array}$ \\
\hline 1 & General purpose plows & 100 \\
\hline 2 & Chisel plows & 80 \\
\hline 3 & Heavy disk harrows & 100 \\
\hline 4 & Light disk harrows & 100 \\
\hline
\end{tabular}

The working tools of tillage machines are mainly subject to abrasive wear. The blade of the soil cutting tools during operation loses its operability due to abrasive wear and therefore it must be reconditioned to eliminate wear. Currently, the main method of hardening the working tools of agricultural machines (earth boards, duckfoot teeth, hoe boot bits, etc.) is the induction surfacing of hard alloys, and the reinforcing materials include high-chromium white irons and powder mixtures: Sormait-1,2; PG-US, PS, PGS, etc. Materials, technology and equipment developed in the 70-80s were widely used. However, at present they do not meet the requirements, including for the operational life of tillage equipment.

\section{Research methods}

The study was based on information materials from Russian scientific and educational organizations and industrial companies, statistics of Rosstat, the Ministry of Agriculture of Russia, product catalogs of major domestic and foreign manufacturers and suppliers of tillage equipment, test reports of tillage machines conducted by machine testing stations, factographic and documentary databases of Rosinformagrotech. The study utilized such methods as information analysis and synthesis, expertise, information and analytical monitoring.

\section{Findings}

Various materials and hardening technologies were developed to increase the wear resistance and durability of working tools (Kryukovskaya, 2020, Erokhin, Kazantsev, Pastukhov, Golubev, 2020). Their analysis made it possible to distinguish three major areas: use of new materials for the manufacture of working tools; hardening of working tools of agricultural machines during their manufacture; higher wear resistance and durability. The Federal Scientific Agroengineering Center VIM analyzed the nature and causes of wear of working tools (bits) of anchor plowshares of Primera DMC-9OOO seeder by Amazone (Germany) to the limit state at the operating time of 60-200 ha. It is proposed to strengthen the bit by combined coating consisting of the following elements: carbide blade, hardbanding, cermet or composite coating, metal ceramic or electric spark coating, bulk hardening of the base material. According to the results of studies and field tests of hardened working tools, two structures of the bit hardening coating were chosen: HFC hardening of the front surface of the PS-14-60 + EIN side surfacing with VK8 alloy and HFC hardening of the front surface with PGS27 alloy combined with boring of the side surfaces with VK8 alloy. Bits hardened with a combined coating and HFC hardening exhibit 1.5-2 times higher 
wear resistance compared to control samples (serial) (Soloviev, Lyalyakin, Aulov, Ishkov, Ivanovsky, Krivochurov, Sokolov, 2014). The technologies for the reconditioning of earth boards, harrow discs and cultivator teeth by ceramic metal coating were also developed. OJSC ANITIM hardens the discs of disc harrows (both for domestic and foreign samples of equipment) by thermal contact cladding with a solid alloy, which increases the life of the working tools of agricultural machines by $1.5-2$ times. The method of carbo-vibro-arc hardening (CVAH) to strengthen the earth boards was developed at Oryol SAU. At present, one of the promising methods is their carbo-vibro-arc hardening using a graphite electrode and composite metal ceramic pastes. This method implies the creation of a metal ceramic coating of paste components on the hardened surface of the working tool during electric arc burning. At the same time, there is hermodiffusion saturation of the working tool metal with alloying elements included in paste and carbon due to its diffusion caused by the sublimation of graphite electrode. Operational performance evaluation of CVAH efficiency was carried out using the example of earth board hardening. This type of working tool is the basic one for many domestic and foreign machines currently used in agriculture for soil tillage (cultivators, sowing complexes, rippers, seeders, etc.) (Titov, Kolomeychenko, Logachev, Bulavintsev, Pupavtsev, Chernyshov, 2015). Field tests were carried out at the above University on John Deere 730 earth boards hardened by CVAH using pastes in comparison with new non-hardened products. A paste containing $60 \%$ steel matrix powder of PG-10N-01 type, $30 \%$ boron carbide and $10 \%$ cryolite was prepared to harden the earth boards. It is shown that the hardening of earth boards by CVAH from the rear side allows increasing their time between failures to $76 \ldots 77$ ha, which is on average 2.1 times higher than that of a serial unhardened earth boards. Thus, the use of the CVAH method allows significantly increasing the wear resistance and life of earth boards of domestic and foreign tillage machines. The method of flame spraying is also proposed for hardening of earth boards. The powder material is heated until it melts and sprayed with a gas jet onto a pre-prepared (sandblasting) surface of the element. The coating hardness reaches 64 HRC. The blades of reinforced teeth by gas-flame spraying have self-tightening effect, and wear resistance of hardened teeth increases by 3.2-4.0 times compared to non-hardened teeth. This hardening method has some disadvantages: high cost of sprayed powders (self-fluxing nickel-based); high material and time costs, since after spraying the coating needs to be melted.

Bryansk SAU developed the technological process of hardening earth boards with an epoxy-sand composite of the following composition: 60-70 pts. wt. of sand filler, 40-30 pts. wt.of epoxy compound with sand particle diameter of $1.0 \mathrm{~mm}$. Before the application of a composite, the reinforcing construction tape is laid on pre-cleaned to metallic luster and defatted surface. The reinforcing tape is glued in the zone of through wiping covering larger perimeter. The tape must have adhesive properties and have a cell size of not more than $3 \mathrm{~mm}$, inhibiting the flow of the composite in the liquid phase due to surface tension forces. Such inhibition allows the coating to be formed in the restored area without significant flow through the through hole. Besides, the film ensures hardening of the composite and performs a reinforcement function, increasing the resistance of the coating to applied shock. The presence of a mesh also increases the adhesion strength of the coating to the recoverable surface and contributes to the uniform distribution of the polymer composite over the curved surface of a mouldboard. This made it possible to make the maximum possible use of the technological and operational capabilities of plowshares and ensure an increase in the operating life by 2.2-2.7 times in comparison with plant-manufactured parts, as well as reduce economic costs by 1.6 times (Mikhalchenkov, Soloviev, Biryulina, 2015).

Plasma spraying may be used for reconditioning and hardening of worn-out surfaces of working tillage tools. To improve the quality of spraying and increase the productivity of the process, an automated set-up was developed at St. Petersburg State Agrarian University. The earth board of a cultivator is fixed on a table. The set-up is started and the coating is sprayed on the tooth due to plasmatron movements. Plasma-401 set-up is used for this. A bundle of quartz rods is placed in a plasma stream, which evaporate under the influence of high temperature, and their vapors settle on the surface of the hardened tooth. In this case, a layer with a thickness of 2-3 $\mathrm{mm}$ and a hardness of up to $64 \mathrm{HRC}$ is formed. It was revealed that the wear resistance of earth boards hardened by this method was increased by 1.5 times compared to non-hardened, as well as the effect of self-sharpening of the cutting parts. The disadvantage of the method is high cost of equipment for hardening with high-frequency plasma sputtering and the need for a highly-qualified operator working on this equipment (Kryukovskaya N.S., 2020).

The Russian State Agrarian University - Moscow Timiryazev Agricultural Academy justified the possibility of obtaining a self-rolling tooth as a result of point hardening of a blade using pulsed electrical contact heating. In loamy soils, the wear rate of standard earth boards is $17.41 \%$ higher than in experimental ones, in sandy soils - by $13.11 \%$, on average loamy soils - by $9.8 \%$. The results of generalization of methods of reconditioning and hardening of working tools of tillage machines are given in Table 2. 
Table 2. Generalization of methods for reconditioning and hardening of working tools of tillage machines

\begin{tabular}{|c|c|c|c|}
\hline $\mathbf{n} / \mathbf{n}$ & Working tool & $\begin{array}{l}\text { Reconditioning and hardening } \\
\text { method }\end{array}$ & Result \\
\hline 1 & Earth board. & $\begin{array}{l}\text { Application of pulse electric- } \\
\text { contact heating. }\end{array}$ & $\begin{array}{l}\text { Reduction of wear intensity in } \\
\text { loamy soils by } 17.41 \% \text { compared } \\
\text { to serial ones. }\end{array}$ \\
\hline 2 & $\begin{array}{l}\text { Earth board } \\
\text { KvernelandGroup. }\end{array}$ & $\begin{array}{l}\text { Welding of steel band with } \\
\text { subsequent } \\
\text { reinforcement. }\end{array}$ & $\begin{array}{l}\text { Increased durability by } 1.2-1.3 \\
\text { times compared to the original } \\
\text { earth board. }\end{array}$ \\
\hline 3 & Earth board. & $\begin{array}{l}\text { Application of epoxy-sand } \\
\text { composites. }\end{array}$ & $\begin{array}{l}\text { Increased durability by } 2.2-2.7 \\
\text { times compared to serial one. }\end{array}$ \\
\hline 4 & $\begin{array}{l}\text { Earth board by Vari Titan } \\
\text { Lemken. }\end{array}$ & $\begin{array}{l}\text { Welding of blade-patch with } \\
\text { subsequent welding of Castolin } \\
\text { PE1229 wear-resistant material. }\end{array}$ & $\begin{array}{l}\text { Life of hardened earth board } \\
\text { during operation in southern } \\
\text { chernozem soils is } 4.6-5.0 \text { times } \\
\text { higher than the serial one. }\end{array}$ \\
\hline 5 & $\begin{array}{l}\text { Anchor seed shoe of Primera } \\
\text { DMC-9OOO seeder by } \\
\text { Amazone (Germany). }\end{array}$ & $\begin{array}{l}\text { Hardening with combined } \\
\text { coating and HFC hardening of a } \\
\text { bit }\end{array}$ & $\begin{array}{l}\text { Increased wear resistance by } 1.5- \\
2 \text { times compared to serial one. }\end{array}$ \\
\hline 6 & $\begin{array}{l}\text { Duckfoot tooth of John Deere } \\
730 \text { sowing machine complex. }\end{array}$ & $\begin{array}{l}\text { Carbo-vibro-arc hardening of } \\
\text { duckfoot teeth. }\end{array}$ & $\begin{array}{l}\text { Increased MTBF by } 2.1 \text { times } \\
\text { compared to serial one. }\end{array}$ \\
\hline 7 & Duckfoot tooth of a cultivator. & $\begin{array}{l}\text { Plasma sputtering at Plasma-401 } \\
\text { unit. }\end{array}$ & $\begin{array}{l}\text { Increased wear resistance by } 1.5 \\
\text { times. }\end{array}$ \\
\hline 8 & $\begin{array}{l}\text { Duckfoot tooth of a sowing } \\
\text { soil-cultivating } \\
\text { Kuzbass (ANITIM). }\end{array}$ & $\begin{array}{l}\text { Application of composite coating } \\
\text { by HFC boriding. }\end{array}$ & $\begin{array}{l}\text { Increased operating life by up to } \\
3-5 \text { times. }\end{array}$ \\
\hline 9 & $\begin{array}{l}\text { Working tools of soil- } \\
\text { cultivating machines. }\end{array}$ & $\begin{array}{l}\text { Heat treatment with additional } \\
\text { hardening by thermocontact } \\
\text { cladding with solid alloy. }\end{array}$ & $\begin{array}{lcc}\text { Increased operating } & \text { life of } \\
\text { agricultural } & \text { machinery } & \text { working } \\
\text { bodies by } 1.5-2 \text { times. } & \end{array}$ \\
\hline
\end{tabular}

\section{Conclusion}

The operational and technological indicators of tillage equipment do not always meet the consumer properties declared by the manufacturer. There are various methods of reconditioning and hardening of working tools that increase their wear resistance and durability. For example, the welding of the blade-patch with subsequent welding of the wear-resistant material Castolin PE1229 allows increasing the life of duckfoot teeth during operation in southern chernozem soils by 4.6-5.0 times. The application of epoxy-sand composites increases the durability of duckfoot teeth by 2.2-2.7 times. Carbo-vibro-arc hardening of duckfoot teeth allows increasing the time between failures by 2.1 times compared to the serial analogues. It was revealed that plasma spraying of powder materials increases the wear resistance of duckfoot teeth by 1.5 times, and also ensures self-sharpening of the cutting parts. The application of pulsed electriccontact heating during hardening of duckfoot teeth reduces the intensity of their wear in loamy soils as compared to original duckfoot teeth by more than $17.41 \%$, and in medium-loamy soils - by $9.8 \%$.

\section{References}

1. A.A. Antonov, I.G. Golubev Materials of the International Scientific and Practical Conference dedicated to the $20^{\text {th }}$ anniversary of the Department of Technical Operation of Transport. pp. 166-169. (Ryazan: Ryazan State Agrotechnological University named after P.A. Kostychev, 2020)

2. M. Erokhin, S. Kazantsev, A. Pastukhov, I. Golubev Engineering for Rural Development. 19. Ser. $19^{\text {th }}$ International Scientific Conference Engineering for Rural Development, Proceedings, pp. 147-152. (2020).

3. N.S. Kryukovskaya Technical service of machines. 58, 3(140), 68-78, (2020)

4. A.M. Mikhalchenkov, R.Yu. Soloviev, Y.Yu. Biryulina Tractors and agricultural machines. 3, 49-51, (2015)

5. S.A. Soloviev, V.P. Lyalyakin, V.F. Aulov, A.V. Ishkov, V.V. Ivanovsky, N.T. Krivochurov, A.V. Sokolov Collections of GOSNITI, 117, 159-167, (2014)

6. N.V. Titov, A.V. Kolomeichenko, V.N. Logachev, R.A. Bulavintsev, I.E. Pupavtsev, 
N.S. Chernyshov Technologies and equipment for villages, 5, 30-32, (2015) 